\section{Asymmetric Copper Hydride Catalyzed Coupling Reaction to Access Chiral Ketones}

Metal-Catalyzed Asymmetric

Synthesis and

Stereoselective

Reactions

\section{Key words}

copper catalysis

hydroarylation

alkenoic acid

aryl alkenes

aralkyl ketones

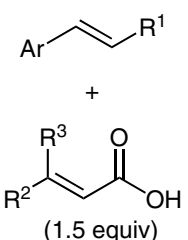

$\mathrm{Cu}(\mathrm{OAc})_{2}(4 \mathrm{~mol} \%)$

(S,S)-Ph-BPE (4.4 mol\%)

$\mathrm{Me}(\mathrm{OMe})_{2} \mathrm{SiH}$ (8 equiv)

THF, $30^{\circ} \mathrm{C}, 24 \mathrm{~h}$

( $\mathrm{NH}_{4} \mathrm{~F}$ workup)<smiles>[R]CC(Br)C(=O)CC([R])[R]</smiles>

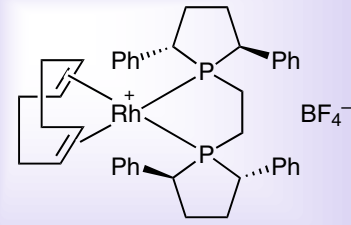

(S,S)-Ph-BPE

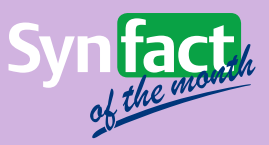

Selected examples:<smiles>CCCC(=O)C(C)c1ccc(F)cc1</smiles><smiles>COc1ccc(C(C)C(=O)CCC(C)C)cc1</smiles>

$84 \%$ yield $91 \%$ ee<smiles>CCCC(=O)C(CCO[Na])c1ccc(-c2ccccc2)cc1</smiles>
$93 \%$ ee<smiles>CC(=O)CCC(C(=O)CC(C)C)c1ccccc1</smiles>
$95 \%$ ee<smiles>CCCCCC(=O)C(C)c1ccc2occc2c1</smiles><smiles>CCCC(=O)C(C)c1ccc(OC)nc1</smiles>

$83 \%$ yield $88 \%$ ee

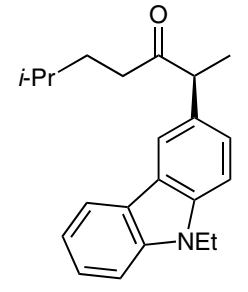

(3)
Significance: The preparation of chiral $\alpha$-aryl dialkyl ketones is an important challenge for the synthesis community. The authors have developed a Cu-catalyzed enantioselective hydroacylation of $\alpha, \beta$-unsaturated carboxylic acids with aryl alkenes.
Comment: This direct asymmetric copper hydride catalysis is highly effective in coupling $\alpha, \beta$-unsaturated carboxylic acids to aryl alkenes to afford the corresponding chiral $\alpha$-aryl dialkyl ketones in moderate yields and with high enantioselectivities.

SYNFACTS Contributors: Hisashi Yamamoto, Wataru Muramatsu

Dol: 10.1055/s-0036-1590772; Reg-No.: H09217SF 